\title{
Temporal Variation in Food Habits of the American Black Bear (Ursus americanus) in the Boreal Forest of Northern Ontario
}

\author{
Derrick A. Romain ${ }^{1,3}$, Martyn E. ObBard ${ }^{2,4}$, and JAmes L. AtKinson ${ }^{1}$ \\ ${ }^{1}$ Department of Animal Science, University of Guelph, Guelph, Ontario N1G 2W1 Canada \\ ${ }^{2}$ Wildlife Research and Development Section, Ontario Ministry of Natural Resources, DNA Building, Trent University, 2140 \\ East Bank Drive, Peterborough, Ontario K9J 7B8 Canada \\ ${ }^{3}$ Current address: Ontario Ministry of Natural Resources, 5520 Hwy 101 E., P.O. Bag 3090, South Porcupine, Ontario P0N 1 H0 \\ Canada \\ ${ }^{4}$ Corresponding author; e-mail: martyn.obbard@ontario.ca
}

Romain, Derrick A., Martyn E. Obbard, and James L. Atkinson. 2013. Temporal variation in food habits of the American Black Bear (Ursus americanus) in the boreal forest of northern Ontario. Canadian Field-Naturalist 127(2): 118-130.

We used scat analysis to investigate temporal variation in the food habits of American Black Bears (Ursus americanus) in the boreal forest of northern Ontario. Specifically, we examined whether there was a seasonal shift in foraging over three years (1990-1992) and which foods, if any, varied in occurrence among years. American Black Bears ate foods ranging from green vegetation in the spring to ants in mid-summer and berries and nuts in late summer and fall. Late summer berry forage, especially blueberries (Vaccinium spp.), varied greatly among years. American Black Bears in northern Ontario consumed a variety of foods opportunistically. Understanding how American Black Bears in northern Ontario exploit food resources and how these food items vary among years can provide insights into demographic processes and help wildlife managers better anticipate changes in the structure of the harvest of American Black Bears and in human-bear conflict levels. In northern Ontario, forest management practices that increase the availability of early successional species would be beneficial to American Black Bear populations.

Key Words: American Black Bear; Ursus americanus; Vaccinium angustifolium; Early Lowbush Blueberry; Vaccinium myrtilloides; Velvet-leaved Blueberry; annual variability; boreal forest; diet; feeding ecology; food habits; foraging; scat analysis; Ontario

Studies of food habits of American Black Bears (Ursus americanus) have covered an array of climatic and geographical locations, from Alaska to Virginia (Hatler 1972; Landers et al. 1979; Beeman and Pelton 1980; Hellgren and Vaughan 1988; Raine and Kansas 1990; Holcroft and Herrero 1991; Schwartz and Franzmann 1991; Boileau et al. 1994; Kasbohm et al. 1995). Nevertheless, such studies should be replicated geographically and temporally because the type, phenology, and relative abundance of foods consumed by American Black Bears vary from location to location and season to season. Natural foods can also vary in abundance among years, significantly affecting survival and reproductive success of American Black Bears (Rogers 1976, 1987; Czetwertynski et al. 2007; Obbard and Howe 2008) as well as space use patterns (Powell et al. 1997).

Variation in the phenology and abundance of natural foods among years has been linked directly to variation in numbers of American black bears that are harvested (Ryan et al. 2004), to changes in the structure of the harvest of American Black Bears (Noyce and Garshelis 1997), and to variation in levels of conflict between humans and American Black Bears (Howe et al. 2010). Adult female American Black Bears are more vulnerable to hunting pressure in the fall during years of food failure (Noyce and Garshelis 1997). As a result, in Ontario, wildlife managers monitor both the total num- ber of American Black Bears harvested and the proportion of females in that harvest to ensure they remain within sustainable levels (McLaren et al. 2009*). Due to the importance of adult females in the population dynamics of American Black Bears (Obbard and Howe 2008), outfitters and other hunters are encouraged to direct harvest towards males (Obbard et al. 2008).

Here we report on the food habits of American Black Bears in the boreal forest of northern Ontario, an understanding of which could help explain variations in the American Black Bear harvest and in levels of conflict between humans and American Black Bears. This knowledge could help wildlife managers understand when to expect increases in the proportion of adult females in the harvest and when to anticipate changes in levels of conflict between humans and American Black Bears.

Because annual variation in natural foods of bears is common, studies of more than two years' duration are necessary to capture annual fluctuations and trends (Korschgen 1980; McLellan and Hovey 1995). Our objectives were (1) to document general food habits of American Black Bears in the boreal forest of Ontario and (2) to determine, over a three-year period, whether there was seasonal and yearly variation in the proportions of food items ingested by American Black Bears in the boreal forest. 


\section{Study Area}

The study area was located approximately $25 \mathrm{~km}$ north of Chapleau, Ontario, in the southeastern portion of the Chapleau Crown Game Preserve $\left(48^{\circ} 10^{\prime} \mathrm{N}\right.$, $83^{\circ} 20^{\prime} \mathrm{W}$; Figure 1 ). A variety of logging roads crisscrossed the $400-\mathrm{km}^{2}$ study area, which was within the Missinaibi-Cabonga Forest Section of the Southern Boreal Forest Region (Rowe 1972). During 19901992, mean temperatures in January and July were $-13.6^{\circ} \mathrm{C}$ and $15.7^{\circ} \mathrm{C}$, respectively; mean annual precipitation was $87.5 \mathrm{~cm}$ (Chapleau Station, $47^{\circ} 49^{\prime} 12^{\prime \prime} \mathrm{N}$, $83^{\circ} 20^{\prime} 48^{\prime} \mathrm{W}$; Environment Canada 2013). The study area was dominated by typical boreal forests with monoculture stands of Jack Pine (Pinus banksiana) and spruces (Picea spp.) along with mixtures of mature boreal mixedwood stands with intermediate successional and recently logged (10-20 years previously) and replanted areas.

Logging and periodic wildfires resulted in a mosaic of different-aged forest stands (Ontario Ministry of Natural Resources 1984*). Major overstory species were Jack Pine, Black Spruce (Picea mariana), White Spruce (Picea glauca), Balsam Fir (Abies balsamea), Trembling Aspen (Populus tremuloides), Paper Birch (Betula papyrifera), Eastern White Cedar (Thuja occidentalis), and Tamarack (Larix laricina), with abundant alders (Alnus spp.), Mountain Maple (Acer spicatum), Balsam Poplar (Populus balsamifera), and willows (Salix spp.) in the understory. Important fruitproducing species in the understory and ground cover were Pin Cherry (Prunus pensylvanica), serviceberries (Amelanchier spp.), mountain-ashes (Sorbus spp.), Beaked Hazelnut (Corylus cornuta), Early Lowbush Blueberry (Vaccinium angustifolium), Velvet-leaved Blueberry (V. myrtilloides), Bunchberry (Cornus canadensis), raspberries (Rubus spp.), currants (Ribes spp.), Bristly Sarsaparilla (Aralia hispida), and Wild Sarsaparilla (A. nudicaulis).

\section{Methods}

Scat analysis is a common technique used to study food habits of carnivores (Klare et al. 2011); however, it can be tedious and labour-intensive, due to the effort required to identify fecal remains. As a result, a number of techniques have been developed to reduce the time required for effective scat analysis. These techniques vary from visual estimates (Tisch 1961; Hatler 1972) to visual volume estimates (Grenfell and Brody 1983; Irwin and Hammond 1985) coupled with frequency of occurrence. Other researchers have used point sampling (Boileau et al. 1994) and volume measured by water displacement (Landers et al. 1979; Holcroft and Herrero 1991).

Because information on dry mass of food items is essential to studies of nutrition or food energetics (Korschgen 1980; Robbins et al. 2004), we elected to base our scat content estimates on the mass of dried, hand-sorted food items in order to make our data avail- able for any future nutritional studies. We also report frequency of occurrence to enable comparison with other studies.

Holcroft and Herrero (1991) arbitrarily suggested that a $25 \%$ subsample should be representative of an entire scat. However, we developed a subsampling technique that showed that a $10 \%$ subsample of each scat was representative of the contents of the entire scat. To determine this, we thoroughly mixed and homogenized one randomly selected dried scat from each season on a dissecting tray and divided each into subsamples. We then compared the contents of $10 \%, 25 \%$, and $65 \%$ subsamples by mass using Spearman rank correlation and found no difference among the three subsample sizes $(P>0.05)$, suggesting that a $10 \%$ dry mass subsample of each scat was sufficient for analysis (Romain 1996).

During May-October 1990-1992, we collected scats daily along a $30-\mathrm{km}$ network of tertiary gravel roads throughout the study area, and occasionally from live traps used to capture American Black Bears for a demographic study (Obbard and Howe 2008). In order to limit bias from anthropogenic sources, we did not collect scats from within a $2-\mathrm{km}$ radius of a small landfill in the study area; this approximated the average radius of the home range of adult female American Black Bears in the area (Schenk et al. 1998). Scats therefore typically contained only naturally occurring foods.

We placed scats separately in labeled plastic bags and froze them at $-20^{\circ} \mathrm{C}$ within 4 hours of collection. For analysis, we thawed individual scats, strained them by washing through three-layered mesh sieves (Precision Scientific Co., Chicago, Illinois; aperture sizes $5.0,2.0$, and $0.833 \mathrm{~mm}$ ) to remove small fragments, and then dried them to a constant mass in a drying oven at $40-50^{\circ} \mathrm{C}$ for $24-48$ hours. We assigned scats to five periods: May, June, July, August, and September-October (September and October were combined because of the small sample sizes).

In order to monitor seasonal availability of plant species that we might expect to find in scats and to obtain representative specimens for comparison with scat contents, we compiled phenological data within major habitat types on a weekly basis from early May to August 1990-1992. We sampled $2010-\mathrm{m}^{2}$ quadrats selected to represent all major habitat types in the study area. We monitored development of a few plant species not found in the quadrats in areas near established quadrats or along roadsides.

After consulting a reference list of plants for the study area (Brunton 1982*), we collected reference samples of potential food items at different phenological stages during 1991, 1993, and 1994, including leaves, berries, and seeds. We collected hairs of known specimens of potential prey animals from carcasses encountered. We also identified food items from fresh scats; this helped us to identify the components of 


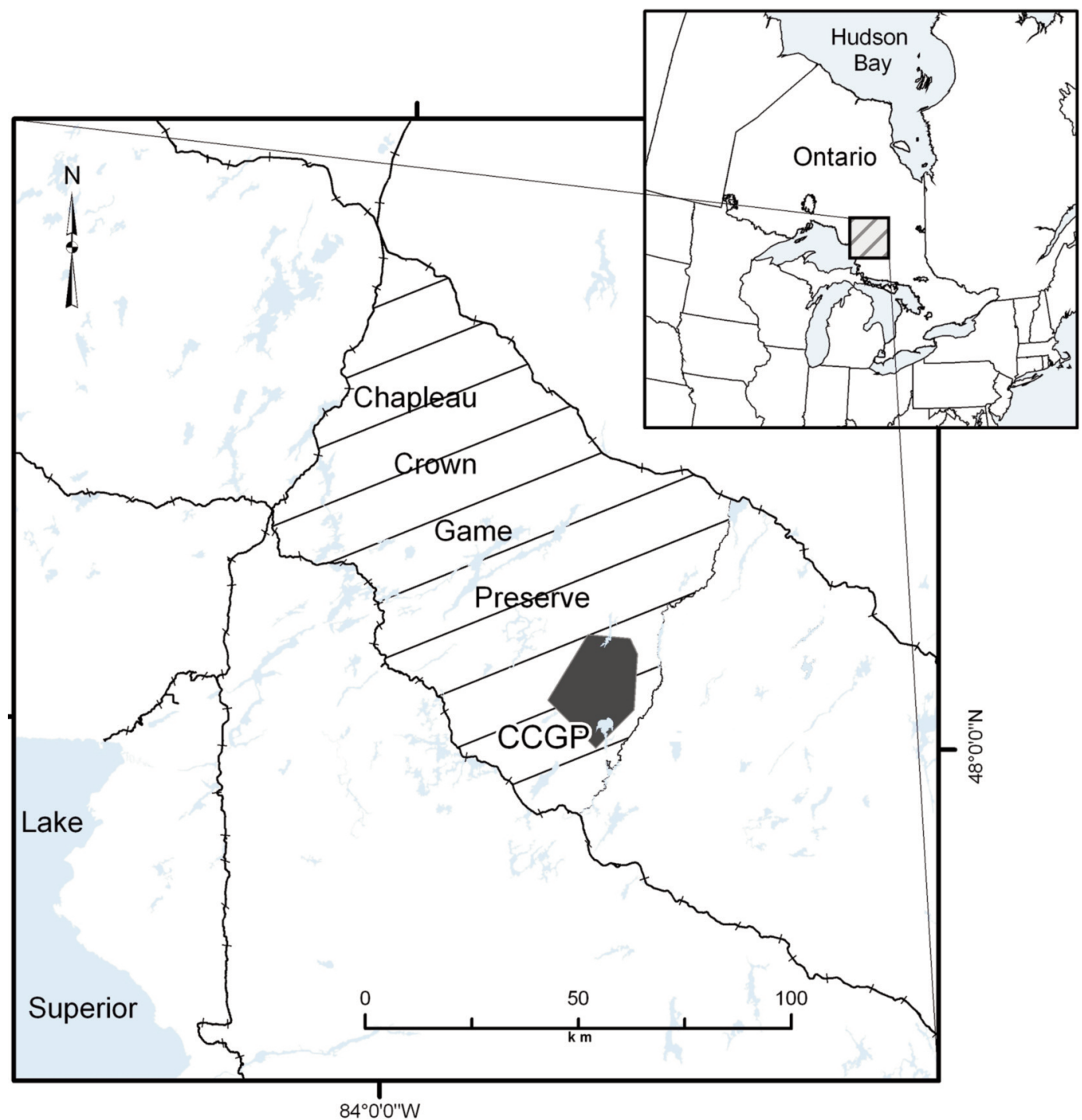

FIGURE 1. Location of study area (black polygon) in the southeastern portion of the Chapleau Crown Game Preserve in northern Ontario, 1990-1992. Inset shows location of Chapleau Crown Game Preserve and surrounding area relative to the rest of the province.

dried scats. We used keys and manuals to identify grasses (Musil 1963; Brown 1979), herbaceous plants, shrubs, and trees (Petrides 1958; Symonds 1963; Peterson and McKenny 1968; Soper and Heimburger 1982; Baldwin and Sims 1989), fruits and seeds (Martin and Barclay 1961; Musil 1963; Montgomery 1977), insects (Bland 1958), and mammal hairs (Adorjan and Kolenosky 1969*; Moore et al. 1974; Thompson et al. 1987). We attempted to separate all species of forbs and herbaceous material, but this was not possible in some scats. Accordingly, we pooled these as "green vegetation."
Our null hypothesis was that diet did not vary among periods and years. We used two-way analysis of variance (ANOVA) (Kuehl 1994; SAS Institute Inc. 1990) to compare the dry mass percentage of individual food item categories among periods and years. We based post-hoc pairwise comparisons on Fisher's least significant difference (LSD) test (Sokal and Rohlf 1981). To approximate normality, we arcsine square root transformed the aggregate percentage mass data (Korschgen 1980). Differences were considered significant at $P<0.05$. 


\section{Results}

During the 1990-1992 field seasons, we collected 1023 scats (373 in 1990, 340 in 1991, and 310 in 1992). The number of scats collected varied somewhat among periods. For example, during the August and September-October periods, no live-trapping was conducted (Obbard and Howe 2008), and fewer scats were found on roads during this period, as some American Black Bears had left the study area on foraging excursions (Obbard and Kolenosky 1994). Of the 1023 scats, we randomly chose 103 for analysis (Tables 1-2).

Amounts of green vegetation differed among months and years (Tables 1-3). During the May and June periods, green vegetation was the major food component ingested; this decreased dramatically during July and August and increased again in September-October. The species of green vegetation that were prevalent, expressed as percentage frequency of occurrence, were clovers (Trifolium spp.), Common Dandelion (Taraxacum officinale), hawkweeds (Hieracium spp.), horsetails (Equisetum spp.), Trembling Aspen, and willows (Table 4). Other items found in high frequency (though not mass) included seeds of Paper Birch, Climbing False Buckwheat (Fallopia scandens), and Tufted Vetch (Vicia cracca) (Table 4).

The amount of grasses and sedges (Grass category) in scats differed among periods (Tables 1-2), but not among years (Table 3 ). The main graminoids (Graminae) eaten were Bluejoint Reedgrass (Calamagrostis canadensis), Fowl Mannagrass (Glyceria striata), and Quackgrass (Elymus repens). The primary sedges (Cyperacae) consisted of Tussock Cottongrass (Eriophorum vaginatum ssp. spissum), Awl-fruit Sedge (Carex stipata), and various other Carex species. Other grasses and sedges found in very small amounts were Fringed
Brome (Bromus ciliatus), Common Timothy (Phleum pretense), bulrushes (Scirpus spp.), Yellow Sedge (Carex flava), and other Carex species.

Fruits were not prominent in the diet until July, August, and September-October. Early emergent berry species such as blueberries, Bunchberry, Skunk Currant (Ribes glandulosum), raspberries, and Wild Sarsaparilla dominated in July (Tables 1-2). Fruits eaten in August were blueberries, Bunchberry, mountain-ashes, Pin Cherry, raspberries, Bristly Sarsaparilla, and Wild Sarsaparilla. The prominent fruit species in SeptemberOctober scats were blueberries, Bunchberry, raspberries, mountain-ashes, and Pin Cherry. Beaked Hazelnut, the only hard mast species found in the study area, was an important food item in September-October. Squashberry (Viburnum edule) was found in only one scat, which was homogeneous for this single food item, thus resulting in a high aggregate percentage mass (Tables 1-2). Alder-leaved Buckthorn (Rhamnus alnifolia), Three-leaf Solomon's Seal (Maianthemum trifolia), Red-osier Dogwood (Cornus stolonifera), serviceberries, and honeysuckles (Lonicera spp.) were found in low frequency.

There was considerable variation among years in some food items (Table 3). For example, a significantly greater amount of blueberries was found in scats in August 1991 than in the other two years (Figure 2). Wild Sarsaparilla was in greater abundance in August of 1990 than in the other two years, and mountain-ashes were in greater abundance in August 1992 than in the other two years (Figure 2). Raspberries varied in frequency of occurrence in August among years, but more greatly in dry mass, with dry mass in 1992 being much lower than in the other two years. Bristly Sarsaparilla was abundant in scats from August 1991, but was not

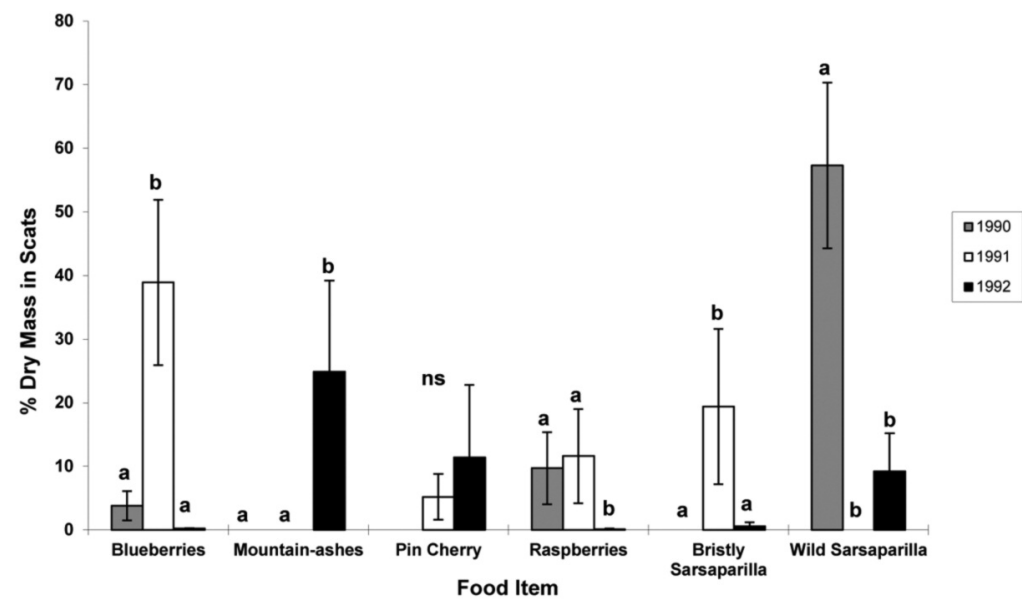

FIGURE 2. Mean percentage dry mass (error bars show standard deviation) of berries that were found in American Black Bear scats $(n=26)$ collected from the Chapleau Crown Game Preserve in August 1990-1992. Different superscripts indicate significant differences $(P \leq 0.05)$ between years. 


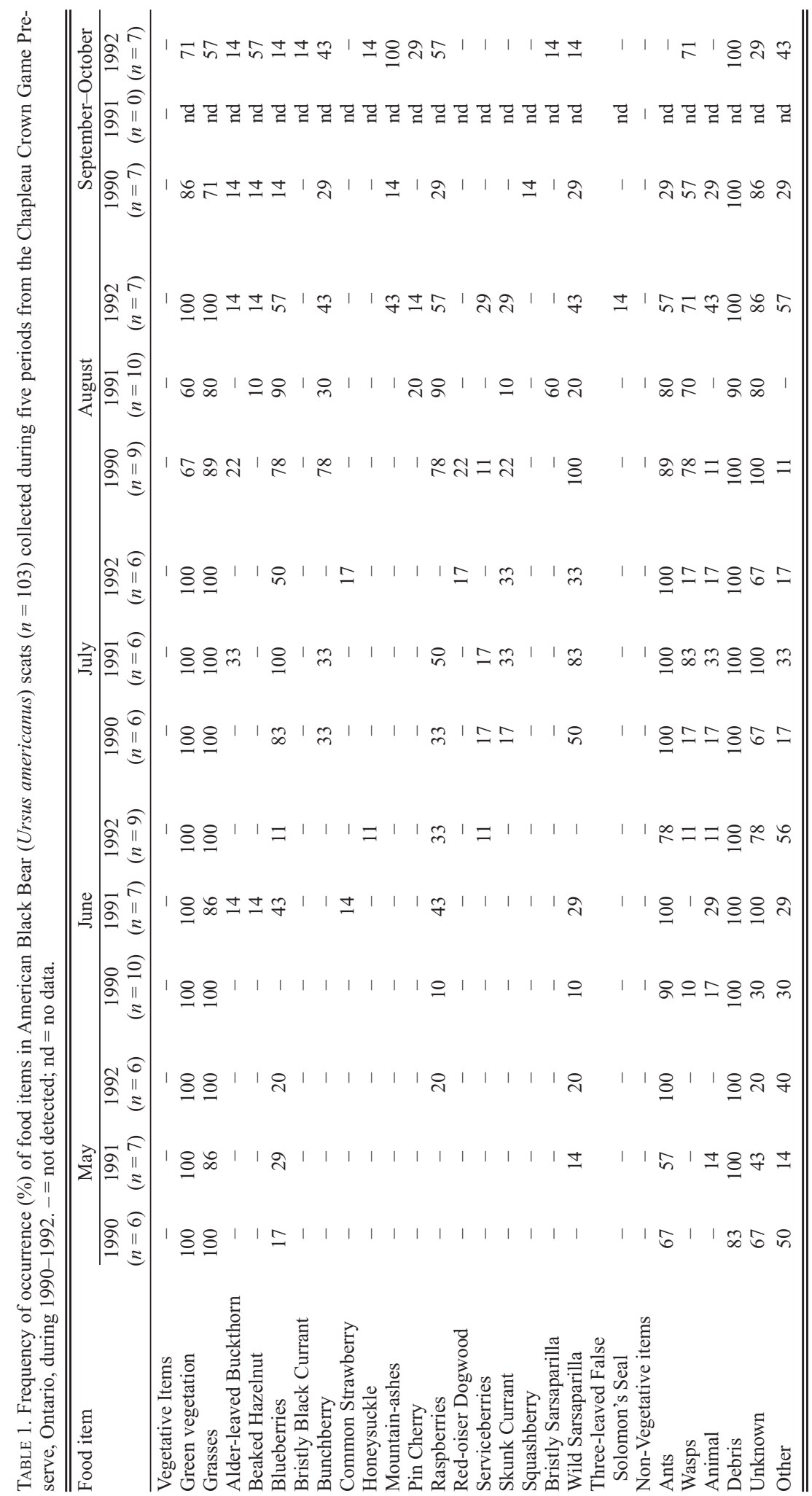




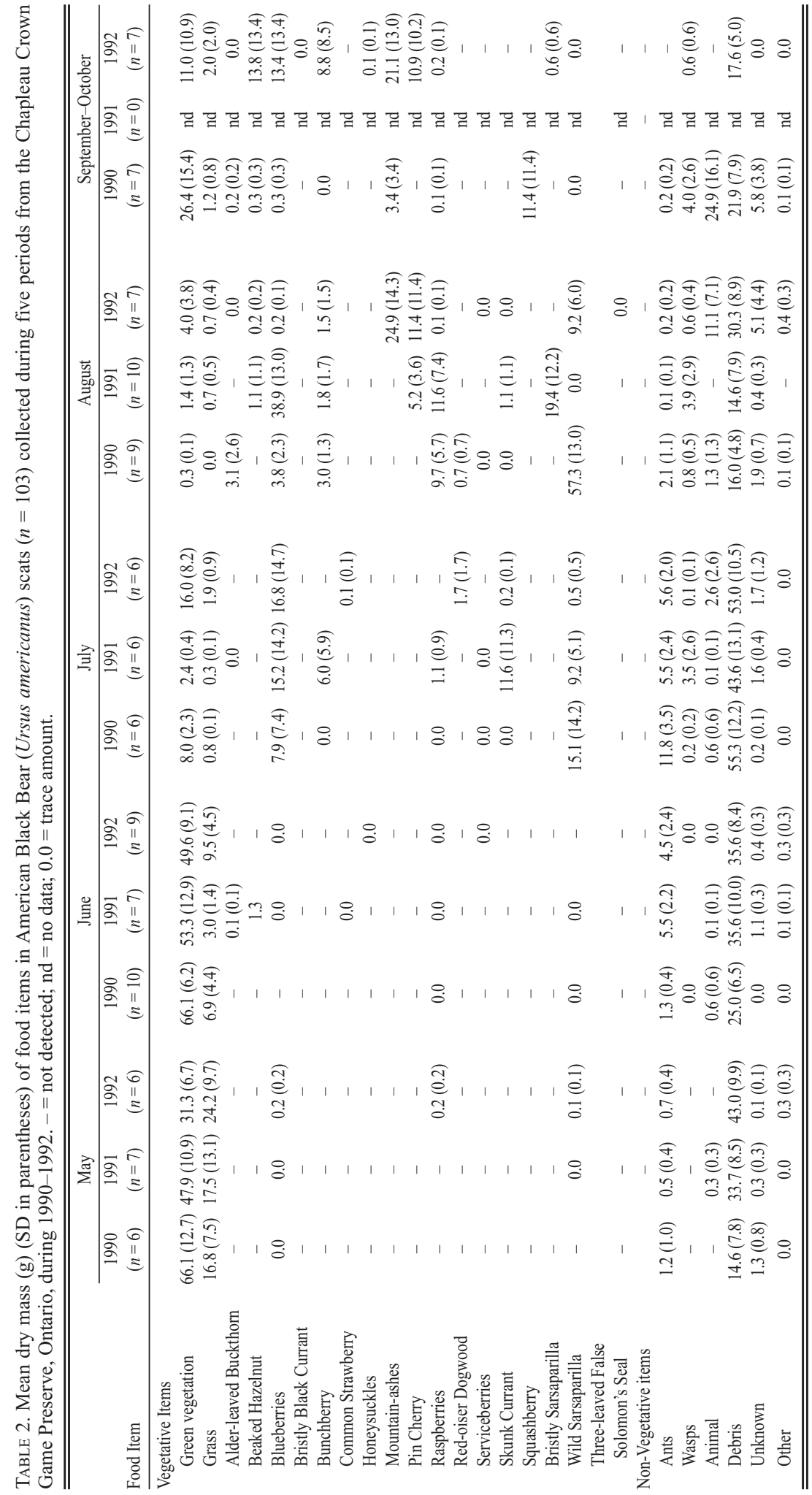


TABLE 3. Two-way analysis of variance (ANOVA) test statistics ( $F$ values and $P$ values) for comparisons of year (three levels_-1990, 1991, 1992) and period (five levels_-May, June, July, August, and September-October) main treatment effects, and their interaction (year • period), on dry mass of American Black Bear (Ursus americanus) food items from scats $(n=103)$ examined from the Chapleau Crown Game Preserve, Ontario. $P$-values in bold were significant at $\alpha=0.05$.

\begin{tabular}{|c|c|c|c|c|c|c|}
\hline \multirow[t]{2}{*}{ Food Item } & \multicolumn{2}{|c|}{ Year } & \multicolumn{2}{|c|}{ Period } & \multicolumn{2}{|c|}{ Year $\bullet$ Period } \\
\hline & $F$ & $P$ & $F$ & $P$ & $F$ & $P$ \\
\hline \multicolumn{7}{|l|}{ Vegetative items } \\
\hline Green vegetation & 3.33 & 0.040 & 37.90 & 0.001 & 0.73 & 0.647 \\
\hline Grasses & 0.80 & 0.451 & 8.51 & 0.001 & 0.24 & 0.975 \\
\hline Alder-leaved Buckthorn & 1.33 & 0.270 & 1.23 & 0.303 & 1.36 & 0.231 \\
\hline Beaked Hazelnut & 0.93 & 0.397 & 2.05 & 0.094 & 0.83 & 0.564 \\
\hline Blueberries & 4.19 & 0.018 & 4.08 & 0.005 & 2.15 & 0.047 \\
\hline Bunchberry & 0.03 & 0.969 & 2.00 & 0.101 & 1.34 & 0.239 \\
\hline Common Strawberry & 0.60 & 0.549 & 0.75 & 0.564 & 1.46 & 0.193 \\
\hline Honeysuckles & 1.62 & 0.204 & 1.13 & 0.349 & 0.70 & 0.671 \\
\hline Mountain-ashes & 6.12 & 0.003 & 3.32 & 0.014 & 2.38 & 0.028 \\
\hline Pin Cherry & 1.56 & 0.216 & 1.66 & 0.167 & 0.66 & 0.704 \\
\hline Raspberries & 2.92 & 0.059 & 6.23 & 0.001 & 1.36 & 0.232 \\
\hline Red-oiser Dogwood & 0.51 & 0.600 & 1.01 & 0.407 & 1.40 & 0.218 \\
\hline Serviceberries & 0.15 & 0.862 & 1.71 & 0.155 & 0.94 & 0.481 \\
\hline Skunk Currant & 2.05 & 0.135 & 1.56 & 0.193 & 1.16 & 0.332 \\
\hline Squashberry & 0.85 & 0.432 & 1.52 & 0.204 & 0.84 & 0.555 \\
\hline Bristly Sarsaparilla & 2.30 & 0.107 & 1.84 & 0.128 & 1.64 & 0.135 \\
\hline Wild Sarsaparilla & 10.71 & 0.001 & 14.06 & 0.001 & 9.39 & 0.001 \\
\hline Three-leaved False Solomon's Seal & 0.61 & 0.543 & 1.38 & 0.246 & 0.69 & 0.684 \\
\hline \multicolumn{7}{|l|}{ Non-Vegetative items } \\
\hline Ants & 0.46 & 0.631 & 17.25 & 0.000 & 1.92 & 0.075 \\
\hline Wasps & 1.51 & 0.226 & 4.22 & 0.004 & 0.86 & 0.541 \\
\hline Animal & 1.28 & 0.283 & 1.77 & 0.141 & 2.43 & 0.025 \\
\hline Debris & 1.59 & 0.211 & 5.58 & 0.001 & 0.97 & 0.458 \\
\hline Unknown & 0.46 & 0.633 & 1.41 & 0.238 & 3.47 & 0.003 \\
\hline Other & 2.07 & 0.133 & 0.28 & 0.891 & 1.24 & 0.290 \\
\hline
\end{tabular}

found in August scats from 1990 or 1992 (it was found in some scats from September-October in 1992).

The mass of ants (Formicidae) in scats varied among periods (Table 3 ). Ants were found in scats throughout the sampling periods, but were found in very high frequency in scats from June and July each year (Tables $1-2)$. Scats contained adult ants, pupae, and larvae in association with large amounts of wood chips. The mass of wasps (Vespidae) varied among periods but not among years (Table 3 ). Wasps were a consistent food source that appeared in scats from June through September-October, but were most prevalent in August (Tables 1-2).

We found significant interactions between year and period for Wild Sarsaparilla, blueberries, mountainashes, animal, and the unknown category (Table 3).

Mammal, bird, and fish remains were found in 15 different scats ( $15 \%$ of total) (Table 4$)$. Snowshoe Hare (Lepus americanus) (4 scats), American Beaver (Castor canadensis) (3 scats), and Moose (Alces americanus) (2 scats) were the mammals most often consumed. Unidentifiable bird remains were found in 4 scats. One scat contained remnants of a variety of mammals along with fish scales and bones (Table 4).

The Unknown component consisted of items which could not be identified, either because we found no suit- able matches or because the items were too small and too well digested to be recognized. The Other category consisted of insects such as beetles (Coleoptera), larvae, roots, and snails. These were likely accidentally ingested, or, in the case of larvae and snails, they may have appeared on the scat after it was deposited.

\section{Discussion}

General results of our study are similar to those of other studies of American Black Bear food habits (Tisch 1961; Irwin and Hammond 1985; Holcroft and Herrero 1991; Boileau et al. 1994), in which green vegetation and grasses comprised the bulk of diets in the spring and soft fruits and hard mast became the major constituents of the diet in summer and fall. However, our study highlights the importance of summer soft mast crops to American Black Bears in the boreal forest and shows the great variation that can occur in these crops among years. For example, 1990 was an average year in terms of vegetation emergence and development in our study area, whereas in 1991 and 1992 vegetation emerged early (Usui et al. 2005). Frosts in late May 1992 destroyed most of the flowers on the earlyflowering berry species such as Early Lowbush Blueberry and raspberries (Chapleau Station: 25 May 1992 minimum air temperature $-4.5^{\circ} \mathrm{C}, 26$ May 1992 mini- 


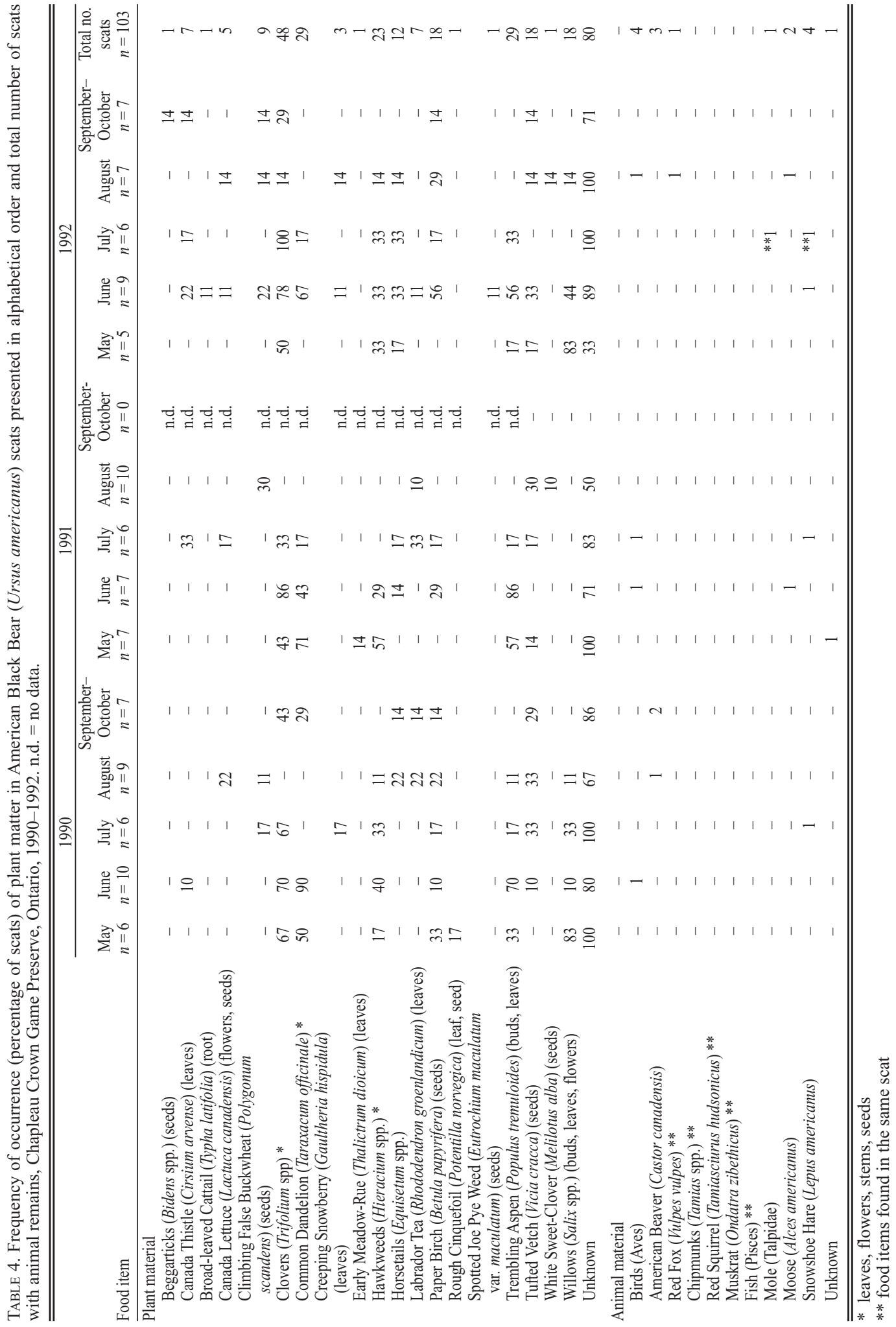


mum air temperature $-2.5^{\circ} \mathrm{C}$; Environment Canada 2013) and had a major impact on the berry crop (Usui et al. 2005). Early Lowbush Blueberry fruits were fully ripened in the third week of July 1991, but no blueberry fruits were available until the second week of August in 1992, when Velvet-leaved Blueberry became available. Velvet-leaved Blueberry generally flowers 2-3 weeks after Early Lowbush Blueberry, so it was not affected by the late frost in 1992. Further, a cool summer resulted in later ripening of other berry crops in 1992 (Chapleau Station: average daily temperature in July 1992 was $13.7^{\circ} \mathrm{C}$ compared to $16.6^{\circ} \mathrm{C}$ in July 1990 and $16.9^{\circ} \mathrm{C}$ in July 1991 ; Environment Canada 2013).

Korschgen (1980) and McLellan and Hovey (1995) suggested that more than two years of data are necessary for food habits studies when annual fluctuations and trends are being described. Results from our study support this view, as they showed distinctly different patterns across three years, particularly in the late summer, when berries were the major food item.

\section{Seasonal variation}

Green vegetation was the most abundant food item in American Black Bear diets in May and June, and consisted predominantly of clovers, Common Dandelion, hawkweeds, Trembling Aspen, and willows (Table 4). All of these species have been reported previously (Tisch 1961; Raine and Kansas 1990; Schwartz and Franzmann 1991; Boileau et al. 1994), although with less prevalence than in our study, suggesting that these species are more important spring foods for American Black Bears in the boreal forest. Clovers, Common Dandelion, and hawkweeds were mostly associated with disturbed areas, such as recent clear-cuts, roadsides, and roadside gravel borrow pits, and Trembling Aspen and willows were common in regenerating clearcuts.

Grasses (Grenfell and Brody 1983; Irwin and Hammond 1985; Schwartz and Franzmann 1991) and horsetails (Hatler 1972; Raine and Kansas 1990) are the dominant food items reported for spring and early summer foraging periods in other studies. In this study, grasses were found in the majority of scats, but only a few scats contained a homogeneous amount. The proportion of grasses in scats is higher than the proportion of grasses in ingested material, since the high cellulose content results in poor digestibility (Grenfell and Brody 1983), whereas succulent forbs are more easily digested. Nevertheless, in our study, grasses were exploited throughout the spring, summer, and fall foraging periods.

Ants were both frequent and abundant in scats during June and July and formed a large proportion of the diet before the onset of the berry season, a pattern also reported by others (Irwin and Hammond 1985; Holcroft and Herrero 1991; Kasbohm et al. 1995; Noyce et al. 1997). Because of the chitinous exoskeleton of ants, the digestibility of adult ants is likely limited. This can introduce bias into scat studies since the proportion of adult ants in scats is likely higher than the proportion in ingested material (compared to larvae, which are presumably highly digestible) (Hatler 1972; Landers et al. 1979; Boileau et al. 1994). Larvae and pupae would be expected to be the target of ant nest raiding due to their high energy and protein content and high digestibility (Noyce et al. 1997). Wasps increased in frequency in scats about the time that ants were declining in frequency in July and August. Other studies have reported wasps to be a component of the diet in late summer or fall (Hatler 1972; Irwin and Hammond 1985; Holcroft and Herrero 1991).

Mammal, fish, and bird remains were found in 15\% of scats in this study. The most common species were Snowshoe Hare, American Beaver, and Moose, similar to the pattern reported by Holcroft and Herrero (1991) and Smith et al. (1994). Animal matter was found in variable amounts and frequency throughout the foraging period, although, unlike other studies (e.g., Schwartz and Franzmann 1991), we did not detect coincidental consumption of Moose calves during the calving season. Schwartz and Franzmann (1991) observed radio-collared calves being killed by American Black Bears, but the low frequency of occurrence of Moose remains in scats in their study confirms the high digestibility of animal matter (Gamberg and Atkinson 1988). The amount of vertebrate remains left in scats likely underestimates the occurrence of these food items in the diet (Putman 1984; Pritchard and Robbins 1990) due to their high digestibility. As such, bone and hair are typically the only components remaining in scats, although these too may be substantially degraded (Gamberg and Atkinson 1988). In addition, American Black Bears typically remove the hide of ungulate prey prior to consumption (Austin et al. 1994), so there would be even less likelihood of finding hairs from young Moose calves in the scats of American Black Bears.

There is anecdotal evidence that American Black Bears in the study area prey on Moose calves (Obbard et al. 2000) and even on adult Moose (Austin et al. 1994). However, it is unknown how commonly such events occur. By comparison, American Black Bears preyed on $11.4 \%$ (5 of 44) of radio-collared Moose calves in a study in Algonquin Provincial Park (Patterson et al. 2013), a protected area with American Black Bear density similar to that in the Chapleau Crown Game Preserve (Howe et al. 2013). Dew claws of Moose calves and other remains were occasionally observed in scats of live-trapped American Black Bears during the current study (MEO, unpublished data); however, under the protocol of our study these particular scats were not randomly selected for analysis. More intensive sampling may be required to detect consumption of Moose calves by scat analysis.

The high incidence of American Beaver remains in fall scats suggests that American Beavers may be more vulnerable to predation by American Black Bears at 
this time, perhaps because American Beavers are harvesting winter food supplies and building food piles (Novak 1987). One scat contained remains of a variety of mammal species as well as fish scales and bones. It is possible that an American Black Bear ingested part or all of a Red Fox (Vulpes vulpes) or other small carnivore that had remnants of the various prey in its own gut contents.

Spawning runs of White Sucker (Catostomus commersonii) were visited by American Black Bears in the study area in spring each year (ca. 15-30 May) (MEO, unpublished data). Some American Black Bears congregated at these creeks, and spawning fish were apparently a substantial food source, as various components (head, tail, lateral muscle, gut, and combinations of these) were missing from carcasses found adjacent to the creeks (DAR, personal observation). However, not all American Black Bears had such creeks within their home ranges, and no fish remains were found in the scats, which were collected at the time and randomly selected for analysis. It appears that our sampling regime was adequate to describe consumption patterns of most food items, especially the important fruit crops, but was insufficient to detect rarely consumed or seasonally highly restricted food items.

The peak of the soft mast season in scats was in August, following the increase of early maturing species such as strawberries (Fragaria spp.), Skunk Currant, Wild Sarsaparilla, raspberries, blueberries, and serviceberries in July and the persistence of some species (raspberries, blueberries) and appearance of later maturing species, such as Alder-leaved Buckthorn, Bunchberry, Pin Cherry, Red-osier Dogwood, and Bristly Sarsaparilla. Later maturing species, such as Beaked Hazelnut, Squashberry, and mountain-ashes, were found in scats in September and October.

\section{Variation among years}

We showed that American Black Bear food habits determined by scat analysis were similar during the spring season over the three years but differed during the summer and fall seasons. This suggests that spring foods in the boreal forest do not differ greatly in abundance among years and so are predictable. In contrast, summer and fall foods vary greatly in abundance among years, and their abundance likely cannot be predicted by American Black Bears.

The breeding season for American Black Bears in Ontario mainly occurs before summer berry crops are available (Kolenosky 1990), and American Black Bears exhibit delayed implantation (Hamlett 1935), meaning that female American Black Bears that are available to mate are pregnant prior to the appearance of summer and fall food crops (even though blastocysts have not implanted). If females do not gain sufficient body mass prior to late fall, implantation does not occur, and those females do not produce a litter; this can affect lifetime reproductive success. As a result, the energetic demands of reproduction during years of food failure can result in adult female American Black Bears looking for anthropogenic sources of food and becoming more prone to come into conflict with humans (Howe et al. 2010).

The greatest variation in amount and frequency of occurrence of berry species among years occurred in the August and September-October periods. There was a significant interaction effect among period and year for blueberries, Wild Sarsaparilla, and mountain-ashes. For example, blueberries were fully ripened in early July in 1990, not until the third week of July in 1991, and not until the second week of August in 1992. The berries of mountain-ashes were significantly more abundant than other berry crops in August 1992, whereas blueberries were significantly more abundant in 1991 and Wild Sarsaparilla was more abundant in 1990. The increased availability of the berries of mountain-ashes in 1992 may have compensated for the loss of the Early Lowbush Blueberry crop due to the killing frost which seriously damaged the flowers in the spring that year. The later flowering species, Velvet-leaved Blueberry, was little affected by the late frost and was the species available by mid-August that year.

The variation in abundance of berry species in the September-October period suggests that Beaked Hazelnut, Bunchberry, mountain-ashes, and Pin Cherry were all exploited to a greater extent in 1992 than in 1990 or 1991, further emphasizing how the availability of food crops for American Black Bears can vary among years, that other food crops may compensate if one food crop fails, and emphasizing that American Black Bears must be adaptable to be able to forage opportunistically. Fruit production in species such as mountain-ashes and Pin Cherry is strongly influenced by fruit production in the prior year, often resulting in an alternating pattern of high and low fruit abundance in consecutive years (Howe et al. 2012), again emphasizing that American Black Bears must be adaptable and forage opportunistically.

Two scenarios have been proposed to explain the effect of food crops on American Black Bear populations. The first is that berry use is limited to a major crop that ultimately regulates population recruitment rates (Jonkel and Cowan 1971; Landers et al. 1979; Beeman and Pelton 1980; Rogers 1987; Elowe and Dodge 1989). The alternative explanation is that American Black Bears use a variety of major berry and mast crops, and switch to alternate foods during times of crop failure (Kasbohm et al. 1996). Results of this study suggest that American Black Bears in the boreal forest will switch to alternate foods when a certain crop fails.

A diversity of soft mast producing species can promote stability if different species are productive in different years (Garshelis and Noyce 2008), and a greater overall diversity of mast species can provide demographic stability (Benson and Chamberlain 2006). However, a long-term demographic study of the population of American Black Bears in the Chapleau Crown 
Game Preserve showed that cub survival was lower during years of food shortages (such as 1992) and litter production rate was lower in years immediately following food shortages (Obbard and Howe 2008). Therefore, in the boreal forest zone of Ontario, where few alternate food crops are available and there can be considerable annual variation in blueberry production (Usui et al. 2005), American Black Bears may not always be able to compensate for the loss of the blueberry crop. This could occur, for example, if a failure of the blueberry crop happened to coincide with a low production year for alternate crops such as Pin Cherry and mountain-ashes. Understanding how summer food items vary in timing and abundance can help wildlife managers better understand the origins of patterns of human-bear conflicts in the boreal forest, and can provide insights into demographic patterns and variation in harvest levels of American Black Bears and population structure. Monitoring the abundance of important food species for American Black Bears on an annual basis would provide the information necessary to test hypotheses generated by these relationships.

Forestry practices in the boreal forest can have a positive effect on the abundance of foods consumed by American Black Bears, because these species increase in abundance in young regenerating forest stands (Brodeur et al. 2008). Early successional areas containing species such as clovers, Common Dandelion, Trembling Aspen, and willows are important foraging areas for American Black Bears in the boreal forest in the spring. In addition, open areas created by wildfire or timber harvesting, especially where Jack Pine is predominant in the overstory, are important foraging areas in summer, when American Black Bears feed on species such as blueberries, serviceberries, and Bristly Sarsaparilla. Because the abundance of such food items varies among years and our study showed that they are important food items in the diet of American Black Bears in the boreal forest, cutover areas or regenerating burns should be protected from the application of herbicides, which can cause a major reduction in fruit production by species such as Vaccinium (Moola et al. 1998).

\section{Acknowledgements}

Support for field work and a graduate student stipend for DAR were provided by the Wildlife Research and Development Section, Ontario Ministry of Natural Resources. We thank the many people involved with the Boreal Black Bear Ecology project based near Chapleau, Ontario, who participated in the study. S. Hollingsworth helped with scat analysis and C. Lacroix assisted with identification of plant and seed samples. W. Szkotnicki provided statistical advice. We thank L. Caston, S. Fava, R. Gurure, E. Howe, T. Jung, G. Kolenosky, T. Nudds, D. Potter, and two anonymous reviewers for advice and comments on earlier versions of the manuscript.
Documents Cited (marked * in text)

Adorjan, A. S., and G. B. Kolenosky. 1969. A manual for the identification of hairs of selected Ontario mammals. Research Report (Wildlife) No. 90. Research Branch, Ontario Department of Lands and Forests, Maple, Ontario. 64 pages.

Brunton, D. 1982. A reconnaissance life science inventory of Missinaibi Provincial Park. Pages 67-77 in Chapleau Crown Game Preserve Management Plan: 1985-2000. Ontario Ministry of Natural Resources, Chapleau, Ontario.

McLaren, M., L. Dix Gibson, T. Armstrong, N. Dawson, M. Obbard, L. Landriault, M. de Almeida, P. Dodwell, R. Black, G. Martin, and B. Radford. 2009. An approach to assessment of harvested black bear populations in Ontario. Southern Science and Information Section Technical Report No. 127. Ontario Ministry of Natural Resources, Southern Science and Information Section, Bracebridge, Ontario. 31 pages.

Ontario Ministry of Natural Resources. 1984. Chapleau Crown Game Preserve Management Plan: 1985-2000. Unpublished report, Ontario Ministry of Natural Resources, Chapleau, Ontario. 94 pages.

\section{Literature Cited}

Austin, M. A., M. E. Obbard, and G. B. Kolenosky. 1994. Evidence for a black bear, Ursus americanus, killing an adult moose, Alces alces. Canadian Field-Naturalist 108: 236-238.

Baldwin, K. A., and R. A. Sims. 1989. Field guide to the common forest plants in northwestern Ontario. Ontario Ministry of Natural Resources, Thunder Bay, Ontario. 344 pages.

Beeman, L. E., and M. R. Pelton. 1980. Seasonal foods and feeding ecology of black bears in the Smoky Mountains. International Conference on Bear Research and Management 3: 141-151.

Benson, J. F., and M. J. Chamberlain. 2006. Food habits of Louisiana black bears (Ursus americanus luteolus) in two subpopulations of the Tensas River Basin. American Midland Naturalist 156: 118-127.

Bland, R. G. 1958. How to know the insects. Third edition. Wm. C. Brown Company, Dubuque, Iowa. 409 pages.

Boileau, F., M. Crête, and J. Huot. 1994. Food habits of the Black Bear, Ursus americanus, and habitat use in Gaspésie Park, eastern Québec. Canadian Field-Naturalist 108: 162169.

Brodeur, V., J.-P. Ouellet, R. Courtois, and D. Fortin. 2008. Habitat selection by black bears in an intensively logged boreal forest. Canadian Journal of Zoology 86: 13071316.

Brown, L. 1979. Grasses: an identification guide. Houghton Mifflin Company, New York, New York. 240 pages.

Czetwertynski, S. M., M. S. Boyce, and F. K. Schmiegelow. 2007. Effects of hunting on demographic parameters of American black bears. Ursus 18: 1-18.

Elowe, K. D., and W. E. Dodge. 1989. Factors affecting black bear reproductive success and cub survival. Journal of Wildlife Management 53: 962-968.

Environment Canada. 2013. Climate data online. National Climate Data and Information Archive. http://climate.wea theroffice.gc.ca/climateData/canada_e.html. Accessed 29 June 2013.

Gamberg, M., and J. L. Atkinson. 1988. Prey hair and bone recovery in ermine scats. Journal of Wildlife Management 52: 657-660. 
Garshelis D. L., and K. V. Noyce. 2008. Seeing the world through the nose of a bear-diversity of foods fosters behavioral and demographic stability. Pages 139-163 in Wildlife Science: Linking Ecological Theory and Management Applications. Edited by T. E. Fullbright and D. G. Hewitt. CRC Press, Boca Raton, Florida.

Grenfell, W. E., Jr., and A. J. Brody. 1983. Seasonal foods of black bears in Tahoe National Forest, California. California Fish and Game 69: 132-150.

Hamlett, G. W. D. 1935. Delayed implantation and discontinuous development in mammals. Quarterly Review of Biology 10: 432-447.

Hatler, D. F. 1972. Food habits of black bears in interior Alaska. Canadian Field-Naturalist 86: 17-31.

Hellgren, E. C., and M. R. Vaughan. 1988. Seasonal food habits of black bears in Great Dismal Swamp, VirginiaNorth Carolina. Proceedings of the Annual Conference of the Southeastern Association of Fish and Wildlife Agencies 42: 295-305.

Holcroft, A. C., and S. Herrero. 1991. Black bear, Ursus americanus, food habits in southwestern Alberta. Canadian Field-Naturalist 105: 335-345.

Howe, E. J., M. E. Obbard, R. Black, and L. L. Wall. 2010. Do public complaints reflect trends in human-bear conflict? Ursus 21: 131-142.

Howe, E. J., M. E. Obbard, and J. Bowman. 2012. Prior reproduction and weather affect berry crops in central Ontario, Canada. Population Ecology 54: 347-356.

Howe, E. J., M. E. Obbard, and C. J. Kyle. In press. Combining data from 43 standardized surveys to estimate densities of female American black bears by spatially explicit capture-recapture. Population Ecology. DOI 10.1007 /s10144-013-0389-y.

Irwin, L. L, and F. M. Hammond. 1985. Managing black bear habitats for food items in Wyoming. Wildlife Society Bulletin 13: 477-483.

Jonkel, C. J., and I. McTaggart Cowan. 1971. The black bear in the spruce-fir forest. Wildlife Monographs 27.

Kasbohm, J. W., M. R. Vaughan, and J. G. Kraus. 1995. Food habits and nutrition of black bears during a gypsy moth infestation. Canadian Journal of Zoology 73: 17711775 .

Kasbohm, J. W., M. R. Vaughan, and J. G. Kraus. 1996. Effects of gypsy moth infestation on black bear reproduction and survival. Journal of Wildlife Management 60: 408-416.

Klare, U, J. F. Kamler, and D. W. MacDonald. 2011. A comparison and critique of different scat-analysis methods for determining carnivore diet. Mammal Review 41: 294-312.

Kolenosky, G. B. 1990. Reproductive biology of black bears in east-central Ontario. International Conference on Bear Research and Management 8: 385-392.

Korschgen, L. J. 1980. Procedures for food-habits analysis. Pages 113-127 in Wildlife Management Techniques. Edited by S. D. Schemnitz. Wildlife Society, Washington, D.C.

Kuehl, R. O. 1994. Statistical Principles of Research Design and Analysis. Duxbury Press, Belmont, California. 686 pages.

Landers, J. L., R. J. Hamilton, A. S. Johnson, and R. L. Marchinton. 1979. Foods and habitat of black bears in southeastern North Carolina. Journal of Wildlife Management 43: 143-153.
Martin, C. M., and W. D. Barclay. 1961. Seed identification manual. University of California Press, Los Angeles, California. 221 pages.

McLellan, B. N., and F. W. Hovey. 1995. The diet of grizzly bears in the Flathead River drainage of southeastern British Columbia. Canadian Journal of Zoology 73: 704-712.

Montgomery, F. H. 1977. Seeds and fruits of plants of eastern Canada and northeastern United States. University of Toronto Press, Toronto, Ontario. 232 pages.

Moola, F. M., A. U. Mallik, and R. A. Lautenschlager. 1998. Effects of conifer release treatments on the growth and fruit production of Vaccinium spp. in northwestern Ontario. Canadian Journal of Forest Research 28: 841851

Moore, T. D., L. E. Spence, and C. E. Dugnolle. 1974. Identification of the dorsal guard hairs of some mammals of Wyoming. Wyoming Game and Fish Department, Cheyenne, Wyoming. Bulletin Number 14. 177 pages.

Musil, A. F. 1963. Identification of crop and weed seeds. Agriculture Handbook Number 219. U.S. Department of Agriculture, Washington, D.C. 17 pages.

Novak, M. 1987. Beaver. Pages 283-312 in Wild Furbearer Management and Conservation in North America. Edited by M. Novak, J. A. Baker, M. E. Obbard, and B. Malloch. Ontario Trappers Association under the authority of the Ontario Ministry of Natural Resources, Toronto, Ontario.

Noyce, K. V., and D. L. Garshelis. 1997. Influence of natural food abundance on black bear harvests in Minnesota. Journal of Wildlife Management 61: 1067-1074.

Noyce, K. V., P. B. Kannowski, and M. R. Riggs. 1997. Black bears as ant-eaters: seasonal associations between bear myrmecophagy and ant ecology in north-central Minnesota. Canadian Journal of Zoology 75: 1671-1686.

Obbard, M. E., G. D. Campbell, and A. Schenk. 2000. Evidence for fatal injury inflicted on a female black bear by a moose. Northeast Wildlife 55: 57-62.

Obbard, M. E., and E. J. Howe. 2008. Demography of black bears in hunted and unhunted areas of the boreal forest of Ontario. Journal of Wildlife Management 72: 869-880.

Obbard, M. E., and G. B. Kolenosky. 1994. Seasonal movements of female black bears in the boreal forest of Ontario in relation to timber harvesting. International Conference on Bear Research and Management 9: 363.

Obbard, M. E., B. A. Pond, A. Schenk, R. Black, M. N. Hall, and B. Jackson. 2008. Suspended baits: can they help hunters distinguish male from female American black bears. Ursus 19: 33-42.

Patterson, B. R., J. F. Benson, K. Middel, K. Mills, and M. E. Obbard. 2013. Moose calf mortality in central Ontario, Canada. Journal of Wildlife Management 77: 832-841.

Peterson, R. T., and M. McKenny. 1968. A field guide to wildflowers. Houghton Mifflin Company, Boston, Massachusetts. 420 pages.

Petrides, G. A. 1958. A field guide to trees and shrubs. Houghton Mifflin Company, Boston, Massachusetts. 431 pages.

Powell, R. A., J. W. Zimmerman, and D. E. Seaman. 1997. Ecology and behavior of North American black bears: home ranges, habitat and social organization. Chapman and Hall, London, UK. 203 pages.

Pritchard, G. T., and C. T. Robbins. 1990. Digestive and metabolic efficiencies of grizzly and black bears. Canadian Journal of Zoology 68: 1645-1651. 
Putman, R. J. 1984. Facts from faeces. Mammal Review 14: 79-97.

Raine, M. R., and J. L. Kansas. 1990. Black bear seasonal food habits and distribution by elevation in Banff National Park, Alberta. International Conference on Bear Research and Management 8: 297-304.

Robbins, C. T., C. C. Schwartz, and L. A. Felicetti. 2004. Nutritional ecology of ursids: a review of newer methods and management implications. Ursus 15: 161-171.

Rogers, L. L. 1976. Effects of mast and berry crop failures on survival, growth, and reproductive success of black bears. Transactions of the North American Wildlife and Natural Resources Conference 41: 431-438.

Rogers, L. L. 1987. Effects of food supply and kinship on social behavior, movements, and population growth of black bears in northeastern Minnesota. Wildlife Monographs 97.

Romain, D. A. 1996. Black bear (Ursus americanus) food habits and the nutrition of reproductive females in northern Ontario. M.Sc. thesis, University of Guelph, Guelph, Ontario. 170 pages.

Rowe, J. S. 1972. Forest Regions of Canada. Forest Service Publication No. 1300. Department of Fisheries and the Environment, Ottawa, Ontario.

Ryan, C. W., J. C. Pack, W. K. Igo, J. C. Rieffenberger, and A. B. Billings. 2004. Relationship of mast production to big-game harvests in West Virginia. Wildlife Society Bulletin 32: 786-794.

SAS Institute Inc. 1990. SAS/STAT user's guide. Volume 2. Version 6. Fourth edition. SAS Institute, Inc., Cary, North Carolina. 1686 pages.

Schenk, A., M. E. Obbard, and K. M. Kovacs. 1998. Genetic relatedness and home-range overlap among female black bears (Ursus americanus) in northern Ontario, Canada. Canadian Journal of Zoology 76: 1511-1519.

Schwartz, C. C., and A. W. Franzmann. 1991. Interrelationship of black bears to moose and forest succession in the northern coniferous forest. Wildlife Monographs 113.

Smith, D. W., D. R. Trauba, R. K. Anderson, and R. O. Peterson. 1994. Black bear predation on beavers on an island in Lake Superior. American Midland Naturalist 132: $248-255$

Sokal, R. R., and F. J. Rohlf. 1981. Biometry. Second edition. W.H. Freeman and Company, San Francisco, California.

Soper, J. H., and M. L. Heimburger. 1982. Shrubs of Ontario. Life Sciences Miscellaneous Publication. Royal Ontario Museum, Toronto, Ontario. 495 pages.

Symonds, G. W. D. 1963. The shrub identification manual. University of California Press, Los Angeles, California. 221 pages.

Thompson, I. D., M. S. Porter, and S. L. Walker. 1987. A key to the identification of some small boreal mammals of central Canada from guard hairs. Canadian Field-Naturalist 101: 614-616.

Tisch, E. L. 1961. Seasonal food habits of the black bear in the Whitefish range of northwestern Montana. M.S. thesis, Montana State University, Missoula, Montana. 108 pages.

Usui, M., P. G. Kevan, and M. Obbard. 2005. Pollination and breeding system of lowbush blueberries (Vaccinium angustifolium Ait. and V. myrtilloides Michx. (Ericacaeae)) in the boreal forest. Canadian Field-Naturalist 119: 48-57.

Received 23 August 2012

Accepted 5 February 2013 